\title{
NEW PRODUCT DEVELOPMENT OPPORTUNITIES IN REZEKNE
}

\author{
Iveta Dembovska1, Violeta Kovalenoka ${ }^{2}$ \\ ${ }_{1}^{1}$ Mg.oec., researcher, Rezekne Academy of Technologies, Rezekne, Latvia, \\ e-mail: Iveta.Dembovska@rta.lv \\ ${ }^{2}$ B.soc.sc., Rezekne Academy of Technologies, Rezekne, Latvia \\ e-mail: violeta.kovalenoka@gmail.com
}

\begin{abstract}
The tourism industry was one of the fastest growing industries in Latvia until the pandemic was declared in 2020, which brought the entire industry to a halt. Before the pandemic, travel trends were already moving towards the type of experience offered by hostels, and consumer demand had grown in the past years. Moreover, the industry data show that the number of travellers who use hostels is growing. There are several lodging opportunities in Rezekne, but there is no economical option, which would be a hostel. The research aim is to study the theoretical aspects of a new product and analyse the opportunities for the creation of a hostel - a new tourism product in Rezekne. The methods used in the research are monographic, synthesis, statistical analysis methods, and a survey. The research allowed making recommendations for the creation of a new tourism producta hostel - in Rezekne. The results of the research and survey showed that hostel-level accommodation is needed in Rezekne.
\end{abstract}

Keywords: hostel, new product, tourism product development.

JEL code: O14, L26, L83.

Received: 29 August 2021 Revised: 10 October 2021 Accepted: 17 November 2021

Published: 10 December 2021

\section{Introduction}

The world economy is now developing faster than ever, because the changes in social attitudes, new technologies, as well as the economic and demographic situation promote changes in business. Lodging has primary importance in the travel and hospitality industry because people who travel to different destinations need a place to stay, rest, and sleep. Hostels are one of the lodging options where several guests rent beds in a shared room, usually with a shared bathroom and kitchen appliances. Due to COVID-19, lodging now also needs to adapt to the newly imposed guidelines.

A hostel can be described as budget-friendly accommodation with a shared room. In hostels, travellers usually have dormitory style rooms; however, nowadays private rooms and hotel type options are also available. Hostels primarily focus on creating a social atmosphere and are cheaper than a hotel. The global hostel market is expected to grow from 4.37 billion USD in 2020 to 5.2 billion USD in 2021 . Such growth is mainly related to the fact that companies are resuming their activity and adapting to the new normal 
while recovering from the impact of COVID-19, which brought restrictions involving social distancing, remote work, and closure of businesses as a result of operational problems. In 2025, the market is expected to reach 5.99 billion USD. The growth in millennial (18-35 years old) travel expenses is the main factor that promotes the growth of the hostel market. Hostels are preferred due to their low cost, lodging experience, convenient locations, and the opportunity to meet other millennial travellers. More than $70 \%$ of hostel travellers are millennials, $15 \%$ of whom have used a hostel in the past 12 months. In the past 12 months, 85\% millennial hostel travellers in the USA have travelled abroad, compared with just $33 \%$ of all USA leisure travellers. The hostel industry has shown rapid growth promoted by millennial travellers (aged 18 to 35), who are willing to spend more money on longer trips and see as much of the world as possible (The Business Research Company, 2021).

The aim of the research is to study the theoretical aspects of a new product and analyse the opportunities for the creation of a hostel - a new tourism product in Rezekne.

To achieve the research aim, the authors have set the following research objectives:

1) A theoretical study of the concept of a new product, its development stages;

2) A study of the tourism industry development trends in Latvia;

3) A study of the new tourism product development opportunities in Rezekne;

4) Making conclusions and recommendations.

Research period: 2015-2020.

Hypothesis: A new tourism product in the sphere of lodging can be developed in Rezekne.

Research novelty: New tourism product development opportunities in Rezekne have been studied and analysed.

Research methods: monographic, synthesis, statistical analysis methods, a survey.

\section{Research results and discussion}

\section{The essence and development of a new product}

A product can be defined as anything we can offer for purchase, use, or consumption which can satisfy a client's need or wish. Several authors have studied the notion of a product. $\mathrm{Ph}$. Kotler believes that a product is more than just a physical object. A product is anything that can be offered on the market to view, purchase, or use. It is anything that can satisfy a need or a wish. Thus, a product can be a physical good, a service, a shop, a person, an 
organisation, a place, or even an idea. Products are tools for reaching an aim, with the aim being the satisfaction of client needs or wishes (Digitālā biznesa rokasgrāmata, 2011; Kotler et al., 2010). A product is a complex of tangible and immaterial attributes, including packaging, colour, price, prestige, and services that satisfy people's wishes and needs (Stanton, 2012). W.Berkowitz, F.Crane, R.Kerin, S.Hartley, and W. Rudelius define a product as goods or services having tangible or intangible properties, which satisfy consumers in exchange for money or another valuable (Berkowitz et al., 2003). Whereas a new product is a truly novel product, which significantly differs from existing and similar products (Stanton et al., 1994). Several types of new products can be distinguished in relation to the company and the market: new products in the world, new product lines, additions to existing product lines, improvements/revisions of existing products, relocation/positioning, cost reduction (Charles et al., 2012).

According to McKinsey data, only 1 in 7 ideas results in a successful product, and approximately $25-40 \%$ of companies suffer failure after just recently started product development stages (McKinsey and Company, 2017). S. Jobs has said: "The people who are crazy enough to think they can change the world are the ones who do" (Ruth, 2015).

New product development can consist of a variable number of stages. Usually these are 5 to 8 development stages, which involve research, observation, business analysis, development, testing, and commercialisation (Kotler et al., 2010; Baker,2007).

Statistics show that more than 30000 new products are launched on the market every year, and $85 \%$ of them fail. Although there are many different reasons for this, one of the most important reasons is that too many products are not carefully prepared for the market. Neglecting one aspect of product development and too much focus on another usually leads to financial loss. Correct management of the product and its development stages allows preventing such consequences and increasing the chance that the product will succeed in the market (Cernivec, 2018).

New products are also introduced in hotels, such as the world's first robotic butler called Botlr was created at Aloft Cupertino, a hotel in the Silicon Valley. The robot moves between hotel floors to serve guests. Robots that integrate voice and face recognition technologies can be placed all around the hotel to provide information about reception services, as well as checking in and checking out. Robots can process many tasks faster than humans (Clements, 2021). 


\section{Tourism industry development trends}

The COVID-19 pandemic, which took over the world just in a few weeks, has not only significantly affected public health but has also had a great impact on one of the primary elements of the global economy - the tourism industry.

According to the World Tourism Organisation data, the number of international tourists in 2020 decreased by 74\%, compared with 2019. This equals to an approximately 1 billion fewer international arrivals, bringing the industry to the level last seen at the end of the 1980s. Due to the new outbreaks and stricter travel restrictions, the arrivals of international tourists (overnight visitors) in January 2021 decreased by $87 \%$, following a $85 \%$ drop in the last quarter of 2020 . By region, in the Asia-Pacific region, which still has the highest level of travel restrictions, the largest decrease in international arrivals was recorded in January (-96\%). Both in Europe and Africa, arrivals decreased by $85 \%$, whereas in the Middle East, an $84 \%$ drop was recorded. International arrivals in the Americas decreased by $77 \%$ in January, following somewhat better results in the last quarter of the year. Given that at the beginning of February 2021, 32\% of global destinations were completely closed and 34\% more were partially closed, UNWTO states that the number of international tourists in the first quarter of 2021 decreased by approximately 85\%, compared with the same period in 2019 (World Tourism Organization, 2021; Hospitality Net, 2021). Since 1980, the number of international travellers has grown exponentially from 277 million to almost 1.5 billion in 2019. The two biggest crises of the past decades - the SARS epidemic in 2003 and the Great Recession in 2009 - were rather small compared with the COVID-19 pandemic. Looking at the future, the majority of experts do not expect full recovery in 2021. UNWTO estimates that the industry is going to need 2.5 to 4 years to return to the pre-pandemic levels of international travel (Rihters, 2021).

After COVID-19, travellers all over the world feel the need to travel to destinations that provide some relief from social distancing. A USA survey conducted by American Express Travel concludes that the coronavirus has changed people's perception of luxury travel because the luxury amenities most valued by the respondents are personalised experience (82\%), high cleanliness standards (81\%), and privacy (79\%). Consumers have also redirected their wishes from the mass tourism sphere to less crowded tourism, especially rural and nature tourism. New alternative and sustainable forms of tourism, as well as the wider territorial distribution of tourists, can accommodate these wishes and help to prevent some undesirable consequences of mass tourism (in cities and towns, tourist villages, famous natural destinations, etc.) (Travel Market Report, 2021). 
Until 2020, tourism was the highest growing industry in Latvia. However, with the introduction of the state of emergency in Latvia in March 2020, the entire industry suffered large losses, which is still happening now. All indicators describing the tourism industry have dropped. The year 2020 was extremely difficult for the travel and tourism industry because the coronavirus breakouts reached all countries and caused the highest level of restrictions ever experienced (fig.1).

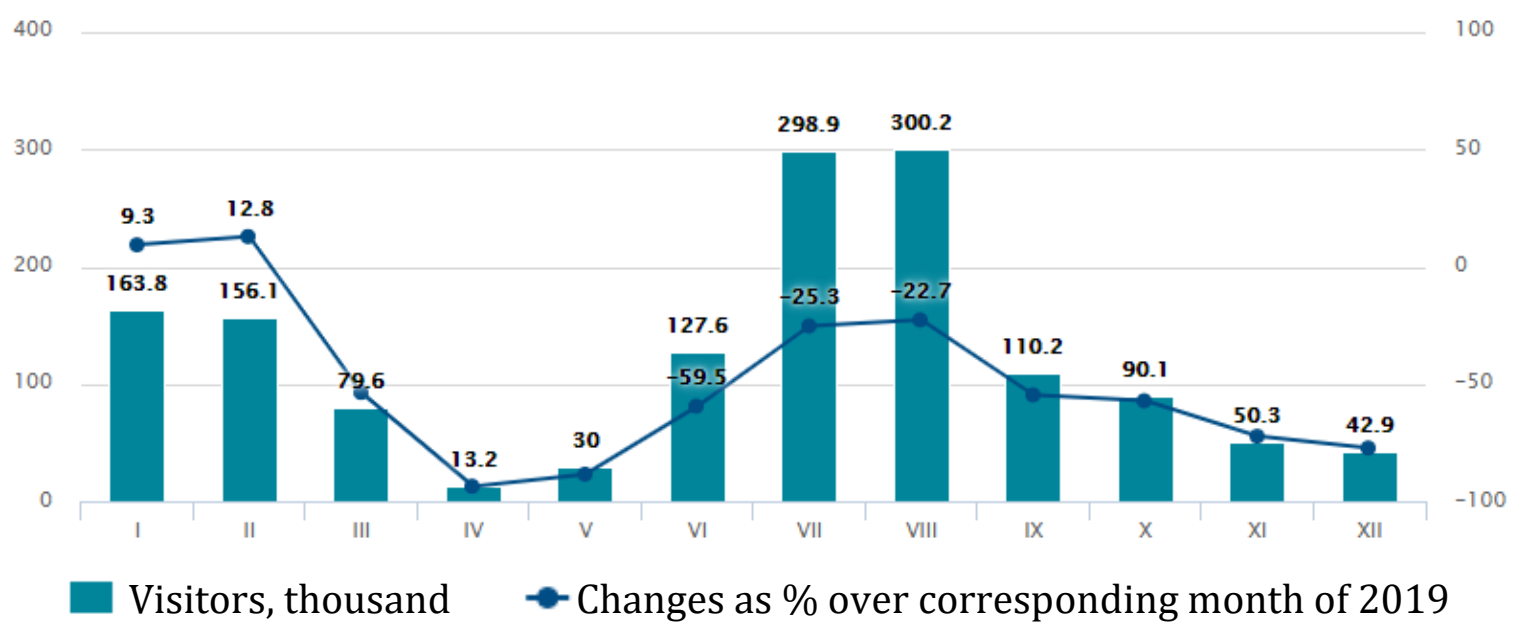

\section{Fig.1 Number of guests served in tourist accommodations in 2020 compared with 2019 (LR Statistikas pārvalde, 2021)}

\section{New tourism product development in Rezekne}

In tourism development, not only the offer but also lodging is important in order to make guests want to stay for longer. An insufficient number of lodging options has been a pressing issue in Rezekne for several years. Although the situation is gradually improving, organisers of large events have to face the same problem every time. The active tourism season in Rezekne begins at the end of spring and lasts throughout the summer. Different events and festivals not only gather local and international participants but also attract several thousands of guests. GORS, the Embassy of Latgale (Latgales vēstniecība Gors) and the local government office Rezekne Culture and Tourism Centre (Rēzeknes kultūras un tūrisma centrs) are the biggest event organisers in the city, which attract the biggest tourist crowds. The total capacity of the three hotels and one hostel available in Rezekne is more than 300 beds, however these organisations face regular difficulty finding a place for their guests (Latgales regiionālā televīzija, 2017).

The number of lodging options in Rezekne has not changed in the past three years. There are six lodging options in the city and no hostels. Lodging availability in the hostel category in Rezekne Municipality: 1 in Malta (20 km from Rezekne) and Golden Fox (12 km from Rezekne in the direction of Ludza). 
A survey was conducted in order to determine the new product development opportunities, the necessity, and potential services. The aim of the survey was to explore people's habits when choosing lodging, the factors that influence the choice, and to determine the services of the potential hostel. 166 respondents randomly selected on social media have been surveyed (02/2021-03/2021). People who travel around Latvia and choose to spend the night in different types of accommodation were invited to participate in the survey, 119 of whom were female and 47 were male. The mean age of the respondents was 31 years.

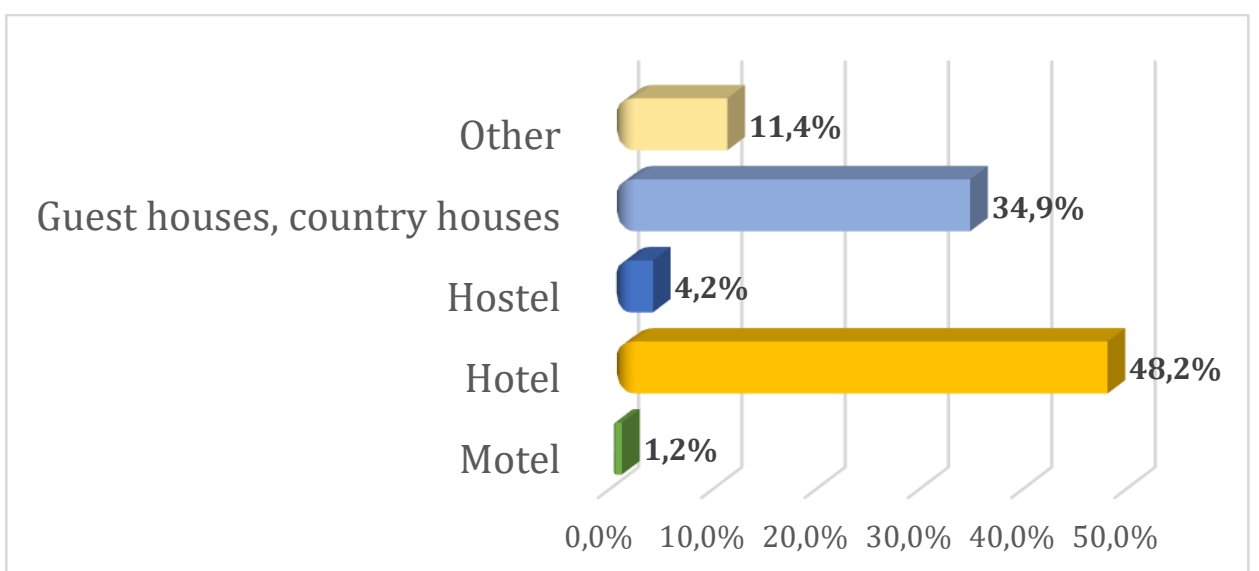

Fig.2. Distribution of the respondents' answers to the question: "What type of lodging do you prefer?" (Created by authors)

As one can see from Fig.2, hostels are preferred by only $4.4 \%$ or 7 respondents. One of the reasons might be their low popularity in Latvia. A very significant difference between a hotel and a hostel is privacy. A hotel room provides a higher level of privacy than a shared room in a hostel.

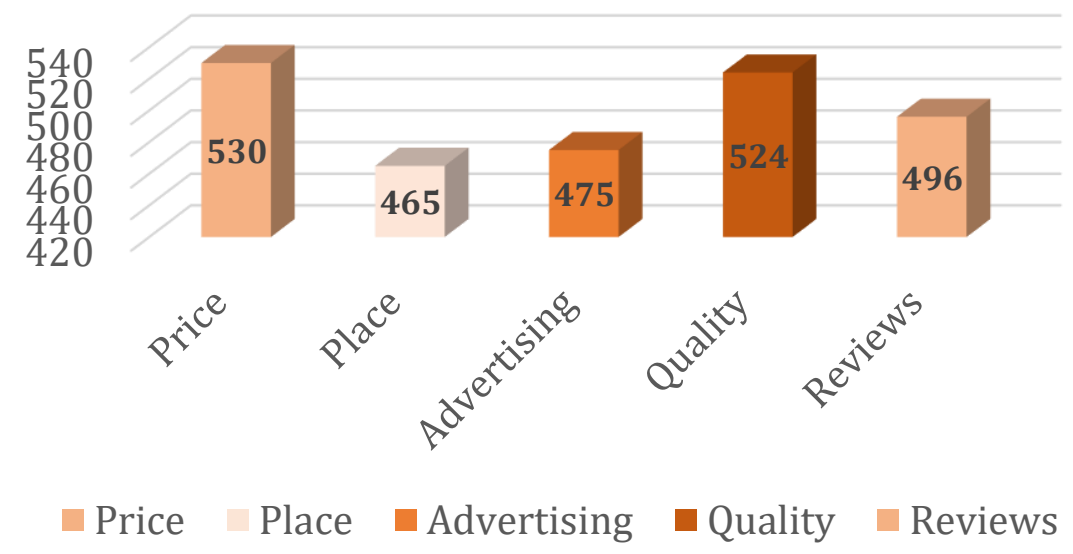

Fig.3. Distribution of the respondents' answers to the question: "Which factor would influence your choice of tourist accommodation?" (Arranged from 1 to 5: 1 - no influence, 5 - large influence) (Created by authors) 
Each of the respondents rated the criterion, assigning it points from 15. Points were added together. The survey results show that the most important factor is the price, which received 530 points, and the second important factor is quality with 524 points. Price and quality are virtually at the same level, with a difference in just two points, which allows concluding that these two factors are the most important factors when choosing lodging. Reviews are in the third place with 496 points. The last two places are taken by the location and advertising. Considering that the mean age of the respondents is 31 years, a conclusion can be made that the location and advertising do not influence the choice of lodging in this age group. Generally, the price of lodging is also determined by its location, furnishings, and the level of services provided.

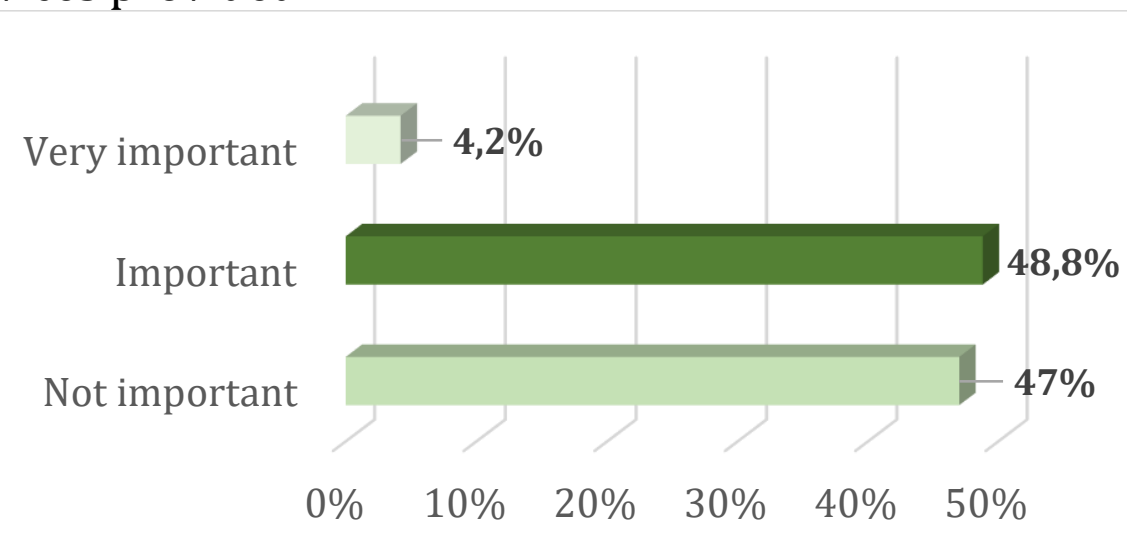

Fig.4 Distribution of the respondents' answers to the question: "How important is it that the lodging is located in the city centre?" (Created by authors)

As one can see from Fig.4, the percentage distribution between Important and Not important is very similar. The option Not important was chosen by $47 \%$ or 78 respondents out of 166; the answer Important was given by $48.8 \%$ or 81 respondents, whereas for $4.2 \%$ or 7 respondents it is very important that the lodging is located in the city centre. This needs to be taken into account when creating a hostel.

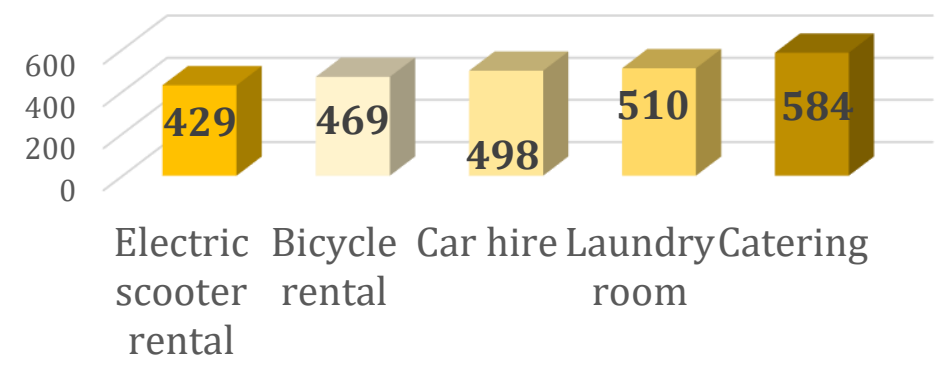

Fig.5 Distribution of the respondents' answers to the question: "What services would you want in a hostel? "(Arranged from 1 to 5: 1 - less important, 5 - very important) (Created by authors) 
Each of the respondents rated the criterion, assigning it points from 15 . Points were added together. The results show that catering has received the largest number of points (584). Self-service is a great option if one does not want to eat outside the hostel or has special dietary requirements. The kitchen usually has sufficient storage space in the cabinets, fridges, and freezers, as well as all the appliances required for cooking, including many pots, pans, tableware and cutlery available for use, which also needs to be provided when creating the new hostel product in Rezekne. The most popular service is followed by the laundry room (510 points). From additional services, car hire has been chosen the most (498 points). Car hire makes it easier for tourists to travel outside the city. There are many tourist destinations outside Rezekne, but getting there is quite difficult.

\section{Conclusions and proposals}

Designing a new product can involve a variable number of stages. These are usually five to eight development stages, which help to understand, analyse, and create the new product, thus reducing the chance of failure. Each new product development stage has its own objectives and goals to achieve using different methods that help to better explore the development stages of the new product, thus helping prevent failure when introducing the product into the market. All new product development stages require equal attention because neglecting one product development stage and too much focus on another usually leads to financial losses and failure.

The COVID-19 pandemic, which took over the world just in a few weeks, has not only significantly affected public health but has also had a great impact on one of the primary elements of the global economy - the tourism industry.

In tourism development, not only the offer but also lodging is important in order to make guests want to stay for longer. An insufficient number of lodging options has been a pressing issue in Rezekne for several years. The current number of lodging options in Rezekne is six, which has remained the same in the past three years.

Although the results of the survey show that the majority of the respondents choose to stay in a hotel, $4.2 \%$ would also stay in a hostel. This proves that different types of accommodation are needed in the city, and entrepreneurs should develop this type of accommodation.

The survey results allow concluding that the most important factor when choosing lodging is the price, followed by quality, as well as catering and car hire services.

When creating a hostel, the new circumstances also need to be taken into account by the entrepreneurs, and a self-check-in kiosk needs to be 
installed for guests, which will ensure contactless registration, reduce reception costs, increase the check-in speed, and provide a room management system.

Entrepreneurs, when creating a hostel, must take into account the balance between price and quality, provide for a larger number of private rooms, offer several additional services, as this was important for the respondents. The location of the hostel does not matter - the city centre or one of the districts of the city.

\section{References}

1. Baker, M. (2007). Marketing strategy \& management. Palgrave Macmillan.

2. Berkowitz, W., Crane, F., Kerin, R., Hartley, S., Rudelius ,W.(2003.). Marketing. (5th ed.)

3. Cernivec, S. (2018). Nielsen: 85 percent of new products fail in the marketplace. Retrieved from https://www.bevindustry.com/articles/87718-nielsen-85percent-of-new-products-fail-in-the-marketplace

4. Charles ,W., Lamb, W., Ch., J.F., Daniel, C.(2012). Marketing. Cengage Learning. (12th edition).

5. Clements, J. (2021). Top 4 hotel technology trends to watch in 2021. Retrieved from https://www.managedoutsource.com/blog/top-4-hotel-technology-trends-watch2021/

6. Digitālā biznesa rokasgrāmata. (2011) Pieci produkta līmeṇi. Retrieved from https://rokasgramata.lv/vadiba/pieci-produkta-limeni/

7. Hospitality Net (2021) Tourist Arrivals Down 87\% In January 2021 As UNWTO Calls For Stronger Coordination To Restart Tourism. Retrieved from https://www.hospitalitynet.org/news/4103715.html

8. Kotler, P., Armstrong, G.(2010). Principles of Marketing. Pearson; (13th Ed.).

9. Latgales reǵionālā televīzija. (2017). Rēzeknē svētku laikā trūkst naktsmìtñu. Retrieved from: https://www.lsm.lv/raksts/zinas/latvija/rezekne-svetku-laikatrukst-naktsmitnu.a225250/

10. LR Centrālās statistikas pārvalde (2021). 2020. gadā tūristu mìtnēs uz pusi mazāk viesu. Retrieved from: https://www.csb.gov.lv/lv/statistika/statistikastemas/transports-turisms/turisms/meklet-tema/2935-latvijas-viesnicu-un-cituturisma-mitnu

11. McKinsey and Company (2017). How to make sure your next product or service launch drives growth. Retrieved from https://www.mckinsey.com/businessfunctions/marketing-and-sales/our-insights/how-to-make-sure-your-nextproduct-or-service-launch-drives-growth

12. Rihters, F.(2021). Tourism Back to 1990 Levels As Pandemic Halts Travel. Retrieved from https://www.statista.com/chart/21793/international-tourist-arrivalsworldwide/

13. Ruth, A. (2015., 24. July.). Steve Jobs - Those Crazy Enough to Change the World. Retrieved from https://due.com/blog/steve-jobs-those-crazy-enough-to-changethe-world/

14. Stanton, W.J. (2012). Prinsip pemasaran, alih bahasa : Yohanes Lamarto Penerbit Erlangga, Jakarta. 
15. Stanton, W.J., Etzel, M.J., Walker, B.J. (1994). Fundamentals of Marketing. McGrawHill Education. (10Rev ed.).

16. The Business Research Company (2021). Hostels Global Market Report 2021: COVID 19 Growth And Change To 2030. Retrieved from https://www.thebusinessresearchcompany.com/report/hostels-market-globalreport-2020-30-covid-19-growth-and-change

17. Travel Market Report (2021). Almost 80\% of Consumers Want to Travel in 2021. Retrieved from https://www.travelmarketreport.com/articles/Almost-80-ofConsumers-Want-to-Travel-in-2021

18. World Tourism Organization (2021). International Travel Largely on Hold Despite Uptick in May. Retrieved from https://www.unwto.org/taxonomy/term/347 